\section{Computers and social options}

from the staff of La Recherche

FOR the first time at the international level, information scientists and computer architects, sociologists and trade union representatives met earlier this month in Vienna to try to cope with the nagging issue of "Computers and Human Choice". Organised under the auspices of the 35-nation International Federation for Information Processing(IFIP) and the Austrian Cybernetic Society, the conference nicely complemented a symposium held two months earlier in Amsterdam, when the International Federation for Automatic Control pondered the problem of "Productivity and Man". Both meetings are clear evidence of the concern shown by professional societies for how today's machines are amplifying human mind and muscle and where the mechanical surrogate leaves man.

The job which the IFIP has set for itself is a big one: in the words of its president, Heinz Zemanek, it is "to stress the social aspects of the computer -to re-establish the human being as the centre of our existence". Large scale information systems have been motivated, to date, largely by industrial and commercial needs. (The military compulsions were not treated by the conferees at Vienna.) Harold Sackman (RAND Corporation) estimated, for example, that the public treasury of the United States has spent about $\$ 100$ thousand million thus far "on the development of computer services of all kinds, and the rest of the world has spent probably the same amount. But the individual citizen is the last to see a direct, useful return on his investment." $\mathrm{Or}$, as expressed more effectively by John M. Carroll (University of Western Ontario), "the computer may be regarded by some as a repressive instrument which serves the causes of governments, corporations and large institutions. The common man too often sees himself as billed by them, taxed, enumerated, administered, manipulated, controlled-creased, folded, spindled and mutilated."

There is hope, nonetheless, that the social options open to the wizards of computing will prove to be more humane in the years to come. Citing a recent report by the Japan Computer Usage Analysis Institute, Alfred Dal. linger of the Austrian trade union of white collar workers reminded the meet. ing of the following time spread noted by the Japanese in the application of large scale information handling systems: 1945-70, 'big science,' 1955-80, the management base, and 1980-2000, the individual base.

With this projection in mind Ulrich
Briefs (West German Trade Union Federation at Dusseldorf) noted that one of the key problems in the long range strategy of organised labour is "whether it is better to fight for an improvement of the situation of employees... with no involvement in management decisions or . . it is more advantageous to participate actively and cooperatively." In other words, does the noninvolvement of the employee in the management process lead to worker alienation? Kristen Nygaard, a computer scientist who is also an executive of Norway's labour union federation, could foresee that trade unions would help improve system design as labour becomes better informed, "as it acquires more information and, therefore, more power in the management-worker relationship. I could not see the unions in my country," he added, "approving the installation of visual terminals on

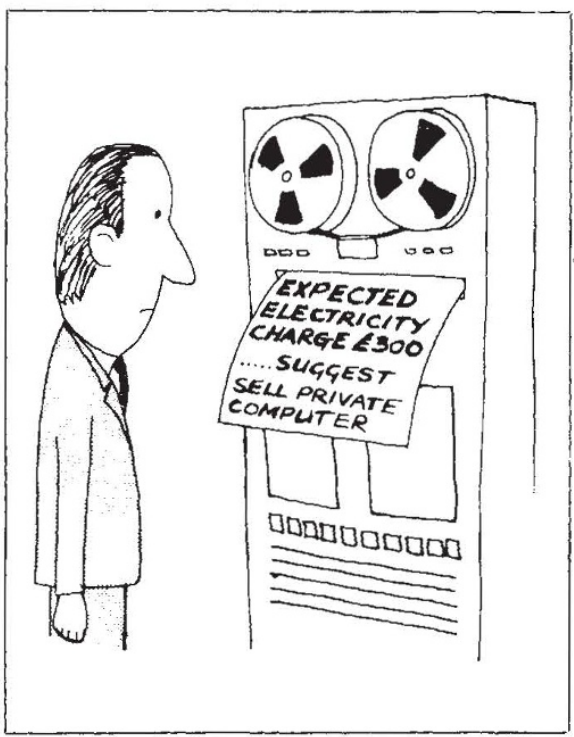

the shopfloor unless these were two-way links."

That the computer is not devoted principally to inventory and marketing problems or to payroll and insurance calculations was evidenced by some of the extensive (and impressive) social applications found for the computer in different geographical and ideological settings. G. R. Waddell, computer comptroller of the Edinburgh Corporation, explained the enormously complex base of accounting, personnel and multiple urban data comprising the municipal management information system (MIS) required to run the city of Edinburgh. Carroll described the experience in London (Ontario) of installing a "people's computer as an aid to democracy", of providing "the common man with easy access to computer facilities to even up the social, economic and political balance of power" in the form of a nongovernmental urban information service in that community. And Burt Nanus, director of the Center for Futures
Research at the University of South California, recalled that a Delphi study made for the American Federation of Information Processing Societies showed how MIS could "strengthen multinational public enterprises in such areas as [education] public health, criminal justice, pollution control, waather forecasting and disaster control, with major impacts before 1985".

An area of principal concern to the IFIP colloquium was that of fair information practices. Bo Hedberg (International Institute of Management, Berlin) emphasised that "we are approaching an information-rich society". System design of the means to process these data usefully, Hedberg continued, "is concerned with the distribution of power, implicitly or explicitly". Willis Ware, an engineer at RAND, proposed the creation by legislative action of a "code of fair information practice or perhaps an Informational Bill of Rights" in an effort to define, nationally then internationally, what is fair behaviour in this realm, "establishing safeguards and deterring deviation by judicial process and appropriate penalties". The IFIP agreed that it will examine the optimal methods, through an ad hoc computersand-society committee, in order to deal with this and similar issues raised during the week-long deliberations.

Although soma expressed the apprehension that "the electronic world is passing us by as we sit here debatingNero fiddling while Rome burns," the last and far from pessimistic word on the subject went to the venerable, Russian-born physicist Lew Kowarski (CERN). He underlined his trust in man's use of the computer when he declared that the latter, "while it will relieve us of burdens, could also relieve us of all that makes life worth living. Before I count on the unforeseen-and therein lies our hope, albeit a pious one. The danger in computers comes not from the experts, but from the profiteers."

\section{Australian answer}

Peter Pockley, Sydney

AfTer studies by various Australian government departments, the Russian request to set un a joint facility "for photographing space objects and studies of the upper atmosphere," reported recently in Nature, has been rejected. The announcement was made on the same day that Prime Minister Whitlam called a snap general election. In the clection atmosphere, the Labour Party could not afford the predictable attacks on grounds of favouring communists above capitalists, even if the scientific arguments in favour of the facility had been sound. 